\title{
Teacher Candidates' Views about Land Art in Geographical Education*
}

\author{
Cengiz KAYACILAR ${ }^{1}$ \\ Niğde Ömer Halisdemir University \\ TURKEY
}

\author{
Ayten KARACA ${ }^{2}$ \\ Niğde Ömer Halisdemir University \\ TURKEY
}

\begin{abstract}
*A portion of this research was presented at the 8. International Social Studies Education Symposium on 7-9 November 2019.

${ }^{1}$ Assist. Prof.; Niğde Ömer Halisdemir University, Faculty of Education, Department of Social Studies Education, Niğde, Turkey. tibetgiz [at] gmail.com. ORCID: 0000-0002-4427-7090

${ }^{2}$ Corresponding author: PhD Student, Niğde Ömer Halisdemir University, Institute of Educational Sciences, Department of Social Studies Education, Niğde, Turkey. aytenkaraca51 [at] gmail.com. ORCID: 0000-0003-3723-7063
\end{abstract}

\begin{abstract}
This study aims to present the views of teacher candidates about the use of Land Art in geographical education, which is an aesthetic application of spatial knowledge. The main reasons for the birth of this research relate to the lack of studies conducted on the use of Land Art practices in the educational environment, together with the idea that its use will contribute to geographical education. In the 2018 - 2019 academic year, during Spring semester, 23 teacher candidates participated in the study. This working group took the second-grade mountain-geography elective course for a Social Studies teaching program at a Faculty of Education in a Turkish university. This research, in which teacher candidates worked in five separate groups to create a land art product, was conducted in the field at Niğde Aladağlar National Park-Emli Valley. At the end of the fieldwork, opinions of the teacher candidates about the land art activity were obtained through inviting their responses to an open-ended questionnaire. Descriptive analysis of the survey data reveals five separate categories including: 'the status of participant knowledge about land art'; 'land art, and formats able to make us of land art in the teaching of Geography in Social Studies'; 'association of art with other disciplines'; 'contribution of Land Art to the teaching of Geography in Social Studies'; and 'Land Art that participants choose as an activity in their professional lives outside of school'. At the end of the field applications, each group filled out the Land Art Product Evaluation Form as the second data collection tool of the research. In the study, it was found that teacher candidates associated Land Art activities with nine courses: Geography; Art and aesthetics; History; Science; Anthropology; Social Studies; Sociology; Archaeology; and Philosophy. At the end of the study, it was observed that all teacher candidates would prefer Land Art activities in their professional lives for various reasons. such as providing permanent learning, providing a fun learning environment, and making the student an active and willing learner.
\end{abstract}

\section{Keywords}

Land Art Activities, Field work, Social Studies Teacher Candidates, Geographical Education 
The impact of Geography, in which humans continue to struggle to exist in all areas, and on human interactions with the environment, have also been investigated in different disciplines.

"The environment in a geographical sense is a living zone in which a person shelters, engages in economic activities, zoning or destroying, and destroys, and in the science of Geography, such circles are called a living zone or just a zone" (Doğanay \& Sever, 2011, p. 12).

The physical environment, which is largely the shaping of individual, social and public life, can be characterized as a giant stage where human activities and events related to life are exhibited. Scientific and technological developments in the process from prehistoric times to the present have provided a number of opportunities for people to establish or rule over the physical environment. At this point in time, extremism was avoided, and this led to some problems for the physical environment.

\footnotetext{
"Especially in the second half of the Twentieth Century, with the rapid development of industrial and technological developments and the possibility of damage to the nature in response to the wrong policies of this development; as well as environmental awareness in the industrial sense, must be kept out of public policy while the havoc related to the emergence of the environmentalist movement and the environmental destruction has led to the formation of ground" (Duran, 2015, p. 26).
}

Events such as the Industrial Revolution, which formed the background of the environmental movement, the capital order, wars, natural disasters, political, human and economic activities, encouraged people to take sides from nature and create elements of reaction in favor of nature. By the 1960s, this reaction appeared in an artistic form. This artistic reaction, which attracted attention with the support of the environmental movement, was previously called Earth Works, Earth Art and Environmental Art, and then announced its existence under the name Land Art.

"It is a movement that began in America with a group of artists whose first manifestations defined themselves as lovers of nature with reactionary attitudes to the conditions of the day; this then developed and expanded to include the entire world, ecology and environmental art, and became defined as Land Art" (Mergin, 2018, p. 34-35).

Land Art originated in the 1960s as a concept (Özayten, 1992; Kedik, 1999; Kedik, 2010; Uzunokur, 2011; Beyoğlu, 2015; Renkçi-Taștan, 2016; Mergin, 2018; Tilki, 2018). The geography of the concept's emergence as an art in those years is in America (Lanzani, 2013; Beyoğlu, 2015) and by the 1970s it has spread to Europe (Tandoğan \& Erdi Es, 2018).

"Although this current is a rebellion against gallery/museum understanding and capitalist understanding, it adopts an environmental understanding and presents large areas of nature to its audience in a unique way by shaping them with a specific concept" (Renkçi-Taştan, 2016, p. 175). With the reaction of the current to the artistic activities taking place between the four walls, the walls were demolished and space in art, the entire surface of the world was accepted. Therefore, this art is a genre in which no limitation can be made on the basis of subject and place. 
"As representatives of land art began to appear in nature, Rachel Carson's book Silent Spring, published in 1962, in which she discussed the negative effects of the use of toxic chemicals in agriculture on nature, contributed to the public becoming more sensitive to environmental issues and the emergence of modern environmentalism. In this sense, it can be said that there are commonalities between environmentalist movements and land art practices" (Çapar, 2015, p. 167).

Born of the environmentalism movement, which can be seen as a dominant cause, Land Art sees nature as a canvas and elements of nature as materials will be used to paint itself. In Land Art, elements of nature are independent of humans, and away from the technical, functional and chemical interventions of humankind. Examples of such elements include stone, soil, sand, rocks, tree leaves, animal feathers or bones, and formations far from human touch, such as ice. The persistence of Land Art activity performed using these elements in nature is limited to the time period during which natural events are allowed, except for human intervention. In other words, the persistence of a Land Art event is as much as rain, flood, wind, or other natural events will allow in the way such elements affect and shape the event. This art is understood to be art of the moment.

\footnotetext{
"Land Art appears in the form of changing nature images by adding new elements, sometimes distorting them, sometimes rearranging them for a protective purpose. Most of the samples were carried out in rural areas, outside the city, especially in the deserts of America. Most of them are experiments abandoned to natural factors that disappear at the end of a day or a certain time" (Özayten, 1992, p. 50).
}

For this reason, it is not expected that Land Art will be constant and continuous like a painting. Although it can be seen that the work of Land Art is still standing when it is returned to the application site. After a while, its permanence is usually up to the first natural event. At the same time, this type of art forms mostly immovable works due to the use of space. In addition, the fact that Land Art has little permanence significantly reduces the likelihood of commodification and creation of markets for humans. In Land Art, the geography in which the application is displayed can be very large areas, as well as a small area. What is decisive in this case is that the land, with all its elements, creates a thought in the mind of the person to whom it addresses. Such thoughts are about how it can use the field. The desire to use a small field with a sufficient number of elements or a field with elements spread over a large area is an indication of the creativity of the individual and the opportunities of the land. Since it is possible for everyone to practice this art in nature, every viewer can also be a Land Art practitioner. Here, the power that makes the viewer a practitioner of art is aesthetic anxiety, including the effort to beautify what appears in the individual, and the use of space or nature to raise awareness of a subject. Although this power that directs the individual to nature can be explained by any current thought, it can be said that Land Art is difficult to explain with an 'ism'. This is because such art is the language of aesthetic touches, awareness, individuality and reaction according to place.

"Contemporary art "non-art" or "anti-form" movements, located within Land Art to expand the application field of the art market, are opposed to activity outside of galleries and museums 
showing the trend of regional ecology awareness and the rediscovery of archaic cultures with (Lynton, 2004), the implementation of the open areas of simple geometric shapes in terms of minimalism, with a stone/with the use of natural materials such as soil and surecsellig in terms of Arte Povera, often due to the transient nature of the work Happening, sometimes even in terms of the artist's focus on the process of personally interfering with nature, performance art and projects are sometimes exhibited only with documents, photographs, maps and similar 'leftover' materials, so it has been characterized as a movement that carries affinity with conceptual art" (Antmen, 2009, p. 253; ref. Yağmur, 2016, p. 1980).

"When we look at the examples of Land Art in the world, which have similarities with many currents in art, there have been differences in studies from America and England. The examples performed in America are more monumental, while the examples in England, in particular, are more romantic, kinder, dimer, more modest studies in harmony with nature." (Kedik, 1999, s. 104).

"The most important Land Art artists "Alice Aycock, Christo, Michael Heizer, Nancy Holt, Walter De Maria, Mary Miss, Dennis Oppenheim, Robert Smithson, Michael Singer, Mel Chin, James Turrell, Ana Mendieta, Alan Sonfist, in Austria Christian Phillip Müller, Jan Dibbets in the Netherlands, Richard Long, Hamish Fulton and Andy Goldsworthy in England" (Antmen, 2014: 251; ref. Tandoğan and Erdi Es, 2018, p. 1360).

No doubt, some of the works of these names are also quite famous examples of this art. Robert Smithson's work Spiral Jetty (Great Salt Lake, Utah-1970), performed in the lake with stone, Earth and salt crystals, is the Woven Branch Circular Arch (Figure 1), performed by Andy Goldsworthy with tree branches (Dumfriesshire/Scotland-1986) and his work Red Leaf Patch (England-1983), which he performed with leaves, are the first works that come to mind among these examples (Tandoğan and Erdi Es, 2018). When the state of art in Turkey is examined, it is seen that history has shifted to the 2000s. The Turkish representatives of this art are Yücel Dönmez, Ayşe Erkmen, Mehmet Ali Uysal, Mehmet Kavukcu, Cengiz Tekin, Mustafa Duyuluer, Varol Topaç and Elçin Ekici (Aydın, 2014). Among the famous works of Turkish artists is Varol Topaç's rolling trees (Figure 2. [South Korea-2006]) and Tamer Serbay's natural miracle (Belgium2006) (Tandoğan and Erdi Es, 2018). Another famous work in art is Mustafa Duyuluer's work called Dream Field I, II and III (Aydın, 2014, p. 43). "Land Art applications in our country have come to the forefront with Andrew Rogers' "Time \& Space"(Figure 3) land art park work in Cappadocia, which is on the World Heritage List" (Rogers, 2019; ref. Çınar and Yirmibeşoğlu, 2019, p. 76). 


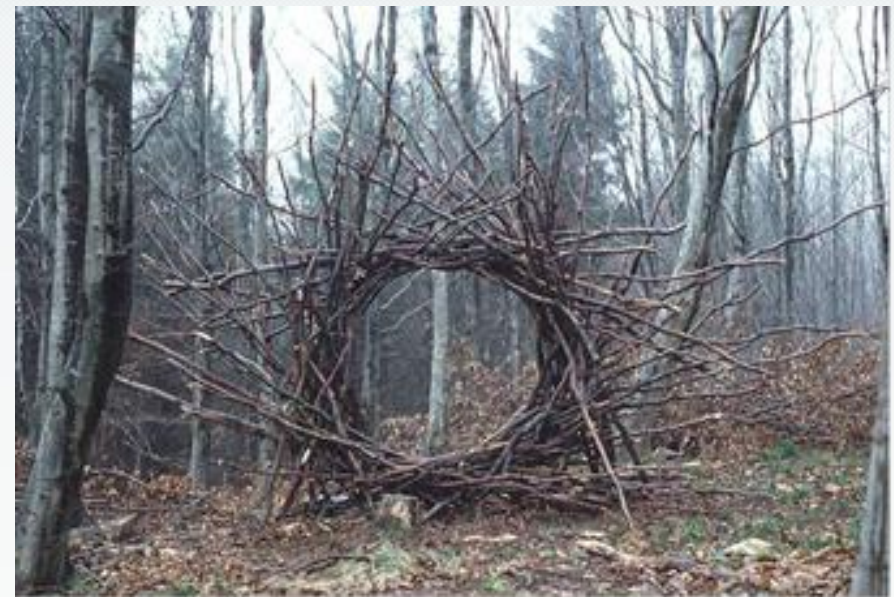

Figure 1. Woven Branch Circular Arch - Andy Goldsworthy, Scotland (Andy Goldsworthy Digital Catalogue, 1986)

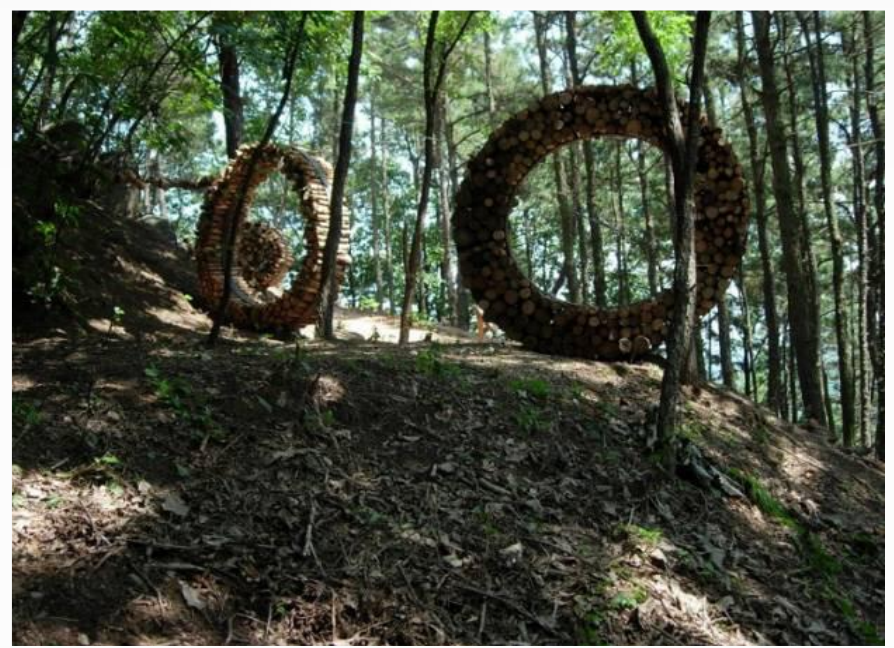

Figure 2. Rolling Trees - Varol Topaç, South Korea, 2006 (http://vtopac.blogspot.com/)

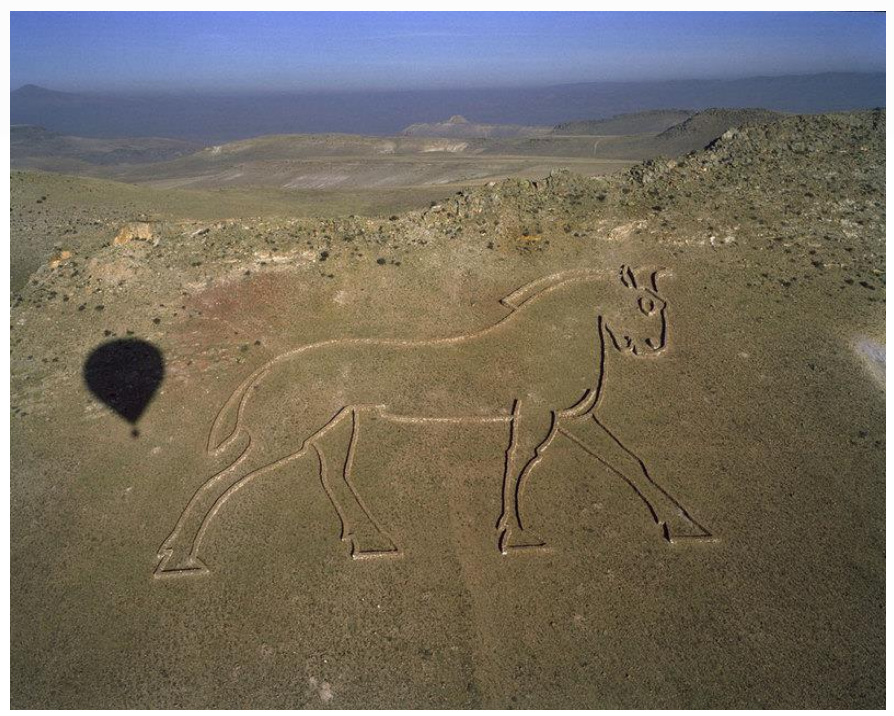

Figure 3. Time and place: Rhythms of life, Gift - Andrew Rogers, Cappadocia-Turkey, 2007 (https://www.andrewrogers.org/) 
As for the use of Land Art in educational activities, there were quite few studies reached in the field of writing. Land Art has been interpreted as an independent art genre rather than being a material referenced in education; related works have been given by passing through the art perspective. In this context, it can be said that the use of Land Art in educational settings has not become widespread.

According to Solberg (2016, p.16), "working with children in the field is part of an existing art practice and activity. It's a way of creativity and engaging in a contemporary culture. In this participation one reaches the dialectic between Earth and form, materiality and mind".

"Working with children and Land Art reveals definitions of identity, culture and tradition, and they show us that the history of the environment in which we live and our human story are intertwined with a kind of logic of necessity or belonging" (Solberg, 2016, p. 18).

"Land Art as an educational and collaborative practice creates a unique mix of art interaction with the pedagogical form" (Solberg, 2016, p. 21). From this point of view, the use of Land Art in education reflects the integration of the child with his identity and culture, based on his experience and the environment in which he lives. This benefit in use indicates that Land Art, as a type of art, should be widely used in achieving targeted goals in the educational environment under the name of land art.

Land Art activity, which is an artistic interpretation of Geography or the physical environment in a spatial sense, has a structure that can be used as a joint expression of knowledge and aesthetics, especially in the teaching Geography. At this point, looking at the examples of Land Art, it can also be interpreted that the product emerges as an expression of creativity, and it is fed from different areas in content or relationally and offers a rich visual as a two-or three-dimensional material that appeals to many senses. "In the teaching-learning process, materials are used to support teaching. Materials selected according to the subject and purpose make the subject taught alive, enrich the teaching process and increase learning. Materials also expand students' interests and increase their motivation" (Demiralp, 2007, p. 374). Especially in the teaching of Geography, visual materials are of great importance and will always maintain this importance because the material of Geography is nature itself.

"For students in an easy-to-learn structure, visual material makes learning faster and more permanent. Some students with learning difficulties can more easily comprehend it with the help of visual material because these materials, above all, provide the basis for attracting attention and staying alive for a long time. In particular, it makes difficult-to-understand concepts simpler and more concrete, causing them to be understood immediately" (Üçışık, Ünlü \& Özey, 2002, p. 2 -3).

Land Art activities are also a material, giving the student the opportunity to experience and embody what they know or design in their mind. The visual richness of a material that has emerged within the scope of Land Art is seen as an opportunity for those who realize Land Art in understanding difficult subjects and providing permanence in learning.

"Due to its multifaceted learning outcomes and the way it facilitates the transfer of what is learned in the classroom to real-life situations, outdoor education has gained much popularity and has been adopted by a variety of disciplines from health to engineering" (Çırak Karadağ, 2019). 
Land Art activities can also be included in outdoor education, which has recently increased its popularity in every field. The fact that Land Art events take place in a space independent of the classroom and school environment can also ensure that land art to be used in education is considered an out-of-school event. As a basis for this idea, Nichols (1982) listed the important characteristics of outdoor school activities as follows.

"Activity should be done outdoors, the participant must be in direct contact with the relevant activities, so the event must contain the original objects, natural elements, an open-air educational activity should identify the relationships, I mean everything else in the universe should be explained the relationship with the event involve the use of multiple senses, so it should appeal to as many senses as possible, and participants for the event must be encouraged and motivated" (Nichols, 1982, p. 2-3).

It is precisely these features of extracurricular activities that define Land Art oneon-one. At this point, in educational activities, using Land Art activities as an out-ofschool activity will be very effective both in achieving the goals of outdoor school activities and in contributing to learning.

"In this context, Social Studies lessons can occur in many different learning environments where students can contribute to the teaching and learning process outside the formal school and classroom environment; in so doing, students can become active learners as they learn-by-doing and learn-by-living" (Aktın, 2020).

Thus, with an application that will take place in the field, students or teacher candidates will achieve the intended gains. No studies were found on the use or status of Land Art activities and their impact on the teaching of subjects within the scope of Social Studies and Geography courses. A study found in the field of Art with a general expression in the teaching of Social Studies and Geography subjects, was found to be quite remarkable.

Yazıcı (2017)'s work 'integration of pebble art in teaching Geography' was carried out with the natural element of the land and pebbles, which are the main material in the study. However, it was found to be outside the scope of Land Art due to the environment in which the study took place and the resulting products include artificial products other than pebble.

The subject of activities performed in the field and used as a material installation instruction in the teaching of two- and three-dimensional thinking would be the contribution of the Arts within the scope of an activity connected to associated disciplines or courses outside the school. This will be seen as a highly effective for Social Studies especially Geography and it was not in literature to work in this regard which has been the main reason for the birth of this research.

In this direction, the aim of the study is to present the views of the teacher candidates on the use of Land Art, as an esthetic application of spatial knowledge in Geography education. For this purpose, the research sought answers to the following questions:

1. What are the views of Social Studies teacher candidates about Land Art? 
- What preliminary information do Social Studies teacher candidates know about Land Art?

- How can Land Art be used in teaching Geography and related subjects in Social Studies?

- How can Land Art, a teaching material and art genre, be associated with various disciplines?

- How does the use of Land Art as a teaching material in an outdoor classroom activity contribute to the teaching of Geography and related subjects in Social Studies?

- What are the views of Social Studies teacher candidates about using Land Art in their professional lives?

2. What are the characteristics of Land Art products created by Social Studies teacher candidates?

\section{Methodology}

\section{Research Design}

This research is a descriptive case study in which the views of Social Studies teacher candidates about Land Art activities are discussed in response to findings from an open-ended survey form and a Land Art Product Evaluation Form.

"In a case study, or case study research, the researcher limits the system (case) or multiplelimited systems (cases) over time. Multi-in-depth information resources (for example, observations, interviews, audio-visual materials, such as documents and reports) that includes detailed data collection tools examined and reported through a qualitative research approach where the definition of the situation and situational themes" (Creswell, 2007, p. 89).

"Case study is a rich descriptor because it relies on deep and diverse sources of information. It uses participatory views, anecdotes, prose from interviews, and other literary techniques to create mental images that bring to life the complexity of the many variables inherent in the phenomenon or subject being studied" (Hancock and Algozzine, 2006, p. 16).

This study aimed to define and determine the scope of Land Art, which is a process activity in accordance with the research pattern, to examine the application process, the benefit of applications, the use and association of applications in different areas.

\section{Working Group}

The research working group consists of 23 undergraduate students who are in their second year of study and attend the Department of Social Studies in a Faculty of Education at a university in Turkey during the 2018-2019 academic year. Seventeen of the teacher candidates are female and six are male. The working group for the research was determined by purposeful sampling methods. "Purposeful sampling allows in-depth research by selecting information-rich cases, depending on the purpose of the study. It is preferred when it is desired to work in one or more special cases that meet certain criteria or have certain characteristics" (Büyüköztürk, Kılıç Çakmak, Akgün, Karadeniz \& Demirel, 2012, p. 90). "If criteria from purposeful sampling methods are sampling, observation units in a study can be created from people, events, objects, or situations with certain qualities. Units 
(objects, events, etc.) that meet the criteria set for the sample in this case), sampling is taken" (Büyüköztürk et al., 2012, p. 91). In this study, the main criteria for determining the participants are completion of the mountain-geography elective course in the fourth semester which was conducted by the first author of the study. The focus is about natural risk areas and education in Turkey, The Physical Geography of Turkey given in the same period as the elective course and is covered by the Technical Land trip in the fourth semester; the General Physical Geography given in the second semester.

These courses, which constitute Geography as a sub-branch, primarily constitute the courses in which visualness is at the forefront. Applying theoretical subjects covered by the course with an understanding of art and aesthetics in the field can be one of the alternative approaches to ensuring permanence in learning and achieving the goals of the courses. The fact that the practices have emerged as products with an artistic and aesthetic aspect in the land are also an indicator that physical geography shows it would be a good and correct decision to consider Land Art activities within the scope of these courses.

\section{The Role of Researchers}

The role of researchers in this study is: to manage the process; to make a division of work among themselves; to act on the land in a sequential manner; to collect data within the scope of the research; to observe impartially and guide students to have a healthy and safe process experience when going to the land; being on the land and returning to the land. The first author of the study described the subject to be covered in the course of mountain-geography and Land Art in the field and then photographed the applications made throughout the process. The second author of the study provided information about how Land Art and its activities were performed, then the second author guided groups to reveal products, helped the teacher candidates to complete their group product evaluations and fill out an openended questionnaire. Researchers impartially monitored the interaction of groups within and with each other through the process in which groups were active in practice and made their own observations at separate points in the field.

\section{Data Collection Tools}

After theoretical knowledge was given in the field within the scope of the mountain-geography course, teacher candidates were asked to form groups and create their own Land Art products in line with the achievements of the course. At the end of the technical fieldtrip, students' views on the process and about Land Art were collected using an open-ended questionnaire consisting of five open-ended questions.

The views of researchers and peer review literature were considered in the openended questionnaire. For teachers, questions were about whether they had prior knowledge about art and Land Art in the teaching of Geography within Social Studies, and how benefit of doing so might occur. As such, for Land Art to be 
associated with the key learning disciplines and contribute to the teaching of the Geography meant that teacher candidates were asked to write their opinions about Land Art as an activity, and also to choose the situations in their professional lives outside of school where they would use Land Art. Participants were given 20 minutes to answer the questions.

\section{The Land Art Product Evaluation Form (LAPEF).}

LAPEF was used as the second data collection tool in the study. The LAPEF covers activities in the land and in the classroom with unstructured observation notes developed by the researchers. The substances that make up the LAPEF were developed by researchers using information from the field and colleague opinions in line with research questions. The LAPEF helped to determine what characteristics of Land Art samples were revealed by groups It is taken into account that the Land Art product has a title and is compatible with its title; that the product promotion is written and presented with clear, clear, scientific statements; and that groups can embody and convey scientific knowledge with the Land Art product. According to these criteria, Land Art products were scored by groups in the form of 1 (insufficient), 2 (medium), 3 (good) and 4 (very good). The scores were then averaged. In addition, observation notes and peer evaluations related to the working process of the groups are included in this one-page form (Table 1). In the observation notes, the group dynamics of the students and the general situations related to the process were taken into account.

In the last 10 minutes of the one-hour period given to the groups for the Land Art event on the land, the participants completed the form presented below in Table 1. Researchers collected these forms from students after in-class activities and filled out the "Observer notes" section. 
Kayacılar, C., Karaca, A., (2020). Teacher Candidates' Views about Land Art in Geographical...

Table 1

Land Art Product Evaluation Form

\begin{tabular}{|c|c|}
\hline \multicolumn{2}{|c|}{ A photo of the band's Land Art product } \\
\hline \multicolumn{2}{|c|}{ 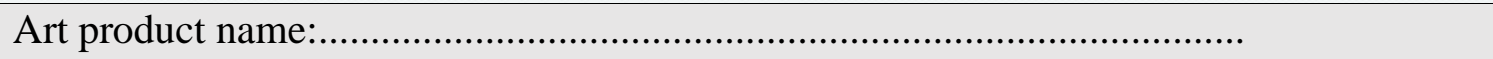 } \\
\hline \multicolumn{2}{|c|}{ 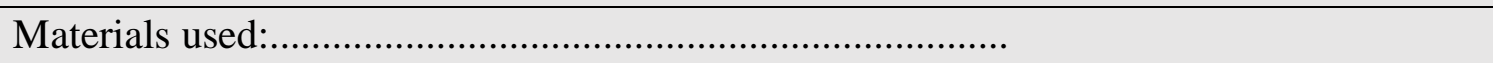 } \\
\hline Number of group elements: ........ & \\
\hline \multicolumn{2}{|c|}{ Product description of the group spokesperson: } \\
\hline \multicolumn{2}{|c|}{$\begin{array}{l}\text { Possible educational attainments } * \text { : } \\
\text { Geography curriculum? What topics they will embody? What value and skills can they } \\
\text { achieve? What discipline can this product most relate to? How will students understand } \\
\text { what this product is? Provide a brief description of the relationship) }\end{array}$} \\
\hline \multicolumn{2}{|c|}{$\begin{array}{l}\text { Average representative score given by all groups } * \text { : } \\
\text { *........................................................................... } \\
\text { and educational terms to each group's Land Art product in a presentation made in the } \\
\text { classroom. (1: Insufficient, 2: Medium, 3: Good, 4: Very Good. These scores are } \\
\text { averaged.) }\end{array}$} \\
\hline Leave this $\quad$ line & $\begin{array}{l}\text { blank. Observer } \\
\text { gap by researchers after collecting forms from } \\
\text { ga....... }\end{array}$ \\
\hline
\end{tabular}

\section{Application Process}

In the spring semester of the 2018-2019 academic year, a Land Art event was held at the technical fieldtrip in Aladağlar National Park-Emli Valley on 20 April 2019. Prior to the event, the researchers' expectation was that the working group could embody the theoretical knowledge learned in practice through natural elements, dexterity and cooperation. During the technical field trip organized with these goals and expectations in mind, students were given information about Land Art. Students were also given time to explore the environment in which they were located to collect natural elements to use on the land. In an environment best suited to the Land Art event, students embodied the natural materials they collected and the knowledge they learned in the lessons. Students formed a total of five groups. The five groups included three groups of four people, one group of six people, and one group of five people. The groups were given an hour to submit Land Art products. In the process of embodying information, students were asked to use not only Geography courses, but also their imagination and their understanding about inter-course associations or disciplines them to be found related. At the end of the period, the groups revealed five separate products. These products were on the snowy ground earth-coordinate system, Aladağlar karst and glacial topography. It was a miniature model of the topography with cracks in the rocks, gravel and clay 
over the cracks, and the infiltration system attaining aesthetic appearance with action representation which emerged out of the gutters filled with a snowy lapya pattern-made of mud and clay to study the decor of the surface of the rock. The cave art is a picture of the sample.

At the end of the event, students completed the Land Art Product Evaluation Form (LAPEF), where they promoted the products they put out in groups. In this form, teacher candidates expressed their views about the products they put forward in the field. They also outlined why they designed this product in a certain way and how they did it. In addition, a spokesperson from each group made a presentation of the form they expressed in writing on the land for Land Art products in the classroom for the next lesson. In addition, during the event process, short observation notes for each group were kept by the researchers and added to the LAPEF after the events.

During the technical field trip, including the application of one-hour Land Art and land transportation from the Faculty of Education in the field, there was the provision of breakfast, lunch and rest time in the course of the meeting, to be held in Aladağlar National Park. This occurred while processing of the geographical formations by walking and transportation by car occurred. The land and of course the processing in the application process included a total of 9 hours. Assessments of the field trip in the classroom were made in the next lesson and lasted two hours. The first hour of evaluation in the class was completed in the form of five separate groups making their presentations.

\section{Analysis of the Data}

The data obtained from the open-ended questionnaire was subjected to descriptive analysis.

\footnotetext{
"According to this approach, the data obtained is summarized and interpreted according to previously determined themes. Data can be organized according to the themes posed by research questions, as well as presented by taking into account the questions or dimensions used in interview and observation processes. In descriptive analysis, direct quotes are often included in order to dramatically reflect the views of the interviewed or observed individuals. In this type of analysis, the aim is to present the results obtained to the reader in an edited and interpreted format. The data obtained for this purpose are first described systematically and clearly. Then these descriptions are explained and interpreted, cause-and-effect relationships are examined, and some conclusions are reached" (Ylldırım \& Şimşek, 2018, p. 239-240).
}

In this study, survey questions prepared in accordance with research questions formed the categories of the study; survey data were encoded and analyzed based on participant opinions. The land art product evaluation form was evaluated using document analysis technique.

"Document review covers the analysis of written materials that contain information about the phenomenon or facts that are intended to be investigated. In qualitative research, document analysis can be a stand-alone data collection method, or it can be used in conjunction with other data collection methods. In cases where direct observation and interview are not possible in qualitative research or in order to increase the validity of the research, written and visual 
Kayacılar, C., Karaca, A., (2020). Teacher Candidates' Views about Land Art in Geographical...

materials and materials related to the research problem may be included in the research, as well as interview and observation methods" (Yıldırım \& Şimşek, 2018, p. 189).

The categories and codes were individually checked by the researchers to increase the validity of the findings from the open-ended questionnaire formed as a result of field surveying and two colleagues' opinions. The answers given by the teacher candidates to the open-ended questionnaire were included in the research as direct quotes to ensure reliability. Accordingly, the teacher candidates who make up the working group were coded by numbers and sorted. For example, a female teacher candidate with a number code of 3 is expressed as ÖK3, and a male teacher candidate with a number code of 6 is expressed as ÖE6.

\section{Findings}

Below, the findings are given in order according to research questions.

\section{Social Studies Teacher Candidates' Views about Land Art Practice}

Five categories were created as a result of descriptive analysis of open-ended survey data to answer the first research question. These:

- The status of participants knowledge about Land Art

- Ways in which to use Land Art in the teaching of Geography and related subjects in Social Studies

- Ways in which participants associate Land Art with other disciplines

- Participants' Views about the contribution of Land Art's to the teaching of Geography and related subjects in Social Studies

- Whether or not participants prefer Land Art as an out-of-school activity in their professional lives

\section{Preliminary Information About the Knowledge Social Studies Teacher Candidates Hold About Land Art}

In this section, the study group's answers to the open-ended questionnaire were discussed within the scope of each relevant question in the study and analyzed based on the participant's opinions. First, teacher candidates were asked whether they had ideas or information about Land Art. Conclusions from teacher candidates about the state of knowledge held about Land Art are given in Table 2.

Table 2

The status of participant knowledge about Land Art

\begin{tabular}{lll}
\hline $\begin{array}{l}\text { Opinion on the state of } \\
\text { knowing Land Art }\end{array}$ & Participants & f \\
\hline $\begin{array}{l}\text { Yes, I know something about } \\
\text { Land Art. }\end{array}$ & ÖK5, ÖK15, ÖK21 & 3 \\
\hline & ÖE1, ÖE2, ÖE3, ÖE4, ÖE6, ÖE7, \\
$\begin{array}{l}\text { No, I do not know anything ÖK8, ÖK9, ÖK10, ÖK11, ÖK12, } \\
\text { about Land Art. }\end{array}$ & $\begin{array}{l}\text { ÖK13, ÖK14, ÖK16, ÖK17, 20 } \\
\text { ÖK18, ÖK19, ÖK20, ÖK22, } \\
\text { ÖK23 }\end{array}$ \\
\hline
\end{tabular}


Table 2 shows the status of knowledge held by teacher candidates about Land Art. Three female students from the study group are understood to have learned about Land Art prior to the event. It was observed that the vast majority of the working group did not know about Land Art before the information and events of this research; and they expressed this situation in the survey form and learned about the activities on the land in this course. Students who have prior knowledge of Land Art have defined the practice as 'the art of land interpretation' (ÖK5), 'the art of product extraction with materials that exist in nature' (ÖK15) and 'the art made with land materials' (ÖK21). Some excerpts from other student opinions are as follows:

"While we had no knowledge of this subject before, as a result of our trip today, we have a lot of knowledge on this subject (ÖE6)."

"No, I had no prior knowledge. I learned it for the first time in this course (ÖK17)."

"I didn't have any information, but thanks to the activity we did today, I learned about what it was and how it was implemented (ÖK23)."

\section{Views of the Candidate Teachers About How Land Art Can Be Used in The Teaching of Geography and Related Subjects in Social Studies}

From the second question of the open-ended questionnaire used in the research, teacher candidate were asked the question about how Land Art as an aesthetic application of spatial knowledge can be used in the teaching of Geography and related subjects in Social Studies. In this question, based on land applications, it was primarily considered whether Land Art can be used in the teaching of Geography and related subjects in Social Studies. The entire working group found Land Art useful in the teaching of Geography and stated that Land Art can be used in teaching such subjects. The unification of teacher candidates views was a the common denominator, and the processes of actively participating in and developing a product accompanied by groups on the ground and their experience and gains from it were effective. The results of the category of ways to in which to use Land Art in the teaching of Geography and related subjects in Social Studies are given in Table 3.

Table 3

How can participants use Land Art in the Teaching of Geography and related subjects in Social Studies

\begin{tabular}{ccc}
\hline $\begin{array}{c}\text { Opinion about how to } \\
\text { benefit from Land Art }\end{array}$ & Participants & f \\
\hline $\begin{array}{c}\text { We can use it to make } \\
\text { theoretical knowledge } \\
\text { permanent. }\end{array}$ & $\begin{array}{c}\text { ÖE1, ÖE2, ÖE3, ÖK5, ÖK8, } \\
\text { OKK9, ÖK10, ÖK11, ÖK12, } \\
\text { ÖK13, ÖK14, ÖK16, ÖK17, } \\
\text { ÖK19, ÖK22, ÖK23 }\end{array}$ & 16 \\
\hline $\begin{array}{c}\text { We can use Land Art } \\
\text { applications as materials and } \\
\text { activities. }\end{array}$ & $\begin{array}{c}\text { ÖE1, ÖE3, ÖK5, ÖE7, ÖK15, } \\
\text { ÖK18 }\end{array}$ & 6 \\
\hline $\begin{array}{c}\text { We can benefit from learning } \\
\text { by doing-living. }\end{array}$ & ÖE1, ÖE4, ÖK9, ÖK20, ÖK21 & 5 \\
\hline We can use it to observe. & ÖK5, ÖK11 & 2 \\
\hline
\end{tabular}


Kayacilar, C., Karaca, A., (2020). Teacher Candidates' Views about Land Art in Geographical...

\begin{tabular}{ccc}
\hline $\begin{array}{c}\text { We can benefit from the } \\
\text { student's active and } \\
\text { interested participation in the } \\
\text { subject. }\end{array}$ & ÖE4 & 1 \\
\hline $\begin{array}{c}\text { In a technology glitch, we can } \\
\text { take advantage of nature. }\end{array}$ & ÖK15 & 1 \\
\hline $\begin{array}{c}\text { We can be injured in } \\
\text { developing your imagination. }\end{array}$ & ÖK19 & 1 \\
\hline $\begin{array}{c}\text { We can benefit in attainment } \\
\text { and awareness about } \\
\begin{array}{c}\text { Geography and sub-branches } \\
\text { of Science. }\end{array}\end{array}$ & ÖE6 & 1 \\
\hline $\begin{array}{l}\text { We can use the knowledge } \\
\text { learned through land art to } \\
\text { pass on to future generations. }\end{array}$ & & \\
\hline $\begin{array}{l}\text { We can use it to educate } \\
\text { students as naturalists. }\end{array}$ & ÖE6 & 1 \\
\hline
\end{tabular}

In Table 3, the views of 23 teacher candidates who made up the working group are reflected about they can use Land Art to teach Geography and related subjects in Social Studies. Teacher candidates proposed multiple strategies for the use of Land Art in teaching Geography. In Table 3, it seems that the benefit most associated with Land Art is that it is believed to assist in making theoretical knowledge permanent. The situation in which teacher candidates can use the theoretical knowledge they have learned from lessons in the field and the application of theoretical knowledge in practice are seen as a reason for the birth of this answer. The case of making theoretical information permanent can also be seen as the most general benefit and final point of the other findings associated with the table. The use of Land Art activities as materials in making theoretical knowledge permanent and the fact that art made the students active throughout the learning process were factors that brought knowledge in theory to permanence through application. In particular, situations such as experiencing the knowledge learned in courses through the process of learning by doing-living, observing and supporting it through the process of developing materials constitute different aspects of making theoretical knowledge permanent.

It can be concluded that views expressed as benefits from the table contain an active process and can also be associated with each other. An example of this situation is the view that information obtained from Land Art through experience and which is largely permanent is transferred to future generations through Land Art. Similar to students in Geography and its constituent scientists like rearing and geomorphology, geographic, vegetation, geography, climatology, Human Geography, Economic Geography, such as achievements and awareness about the views and sections-by-learning by doing and experiencing, observation, and active participation with interest is another example of a situation with which it is associated.

When Table 3 is examined, it is seen that the use of Land Art in the teaching of Geography and related subjects in Social Studies is not limited only to Geography, and the use of Land Art contains statements that can also be generalized for other 
courses. Some of the teacher candidate's views that include these statements include:

"We can use land art applications as materials and activities (ÖK5)."

"We can benefit from learning by doing-living (ÖK20)."

"We can use observation (ÖK11)."

\section{Teacher Candidates' Views About the Disciplines That Can Be Associated with Land Art}

The status of teacher candidates who associate Land Art with other disciplines is given in Table 4.

Table 4

Participant association of Land Art with other disciplines

\begin{tabular}{|c|c|c|}
\hline $\begin{array}{c}\text { Discipline with which Land } \\
\text { Art is associated }\end{array}$ & Participants & f \\
\hline Geography & $\begin{array}{c}\text { ÖE1, ÖE2, ÖE3, ÖE4, ÖK5, } \\
\text { ÖK9, ÖK10, ÖK12, ÖK13, } \\
\text { ÖK15, ÖK16, ÖK17, ÖK18, } \\
\text { ÖK20, ÖK21, ÖK23 }\end{array}$ & 16 \\
\hline Art and esthetics & $\begin{array}{c}\text { ÖE2, ÖE3, ÖE4, ÖK5, ÖK11, } \\
\text { ÖK13, ÖK14, ÖK16, ÖK18, } \\
\text { ÖK20, ÖK22, ÖK23 }\end{array}$ & 12 \\
\hline History & $\begin{array}{c}\text { ÖE1, ÖE2, ÖE4, ÖE6, ÖE7, } \\
\text { ÖK9, ÖK10, ÖK12, ÖK16, } \\
\text { ÖK17, ÖK19, ÖK21 }\end{array}$ & 12 \\
\hline Science & ÖE7, ÖK12, ÖK15 & 3 \\
\hline Anthropology & ÖE1, ÖK9, ÖK15 & 3 \\
\hline Social Studies & ÖK19, ÖK23 & 2 \\
\hline Sociology & ÖK8 & 1 \\
\hline Archaeology & ÖK17 & 1 \\
\hline Philosophy & ÖK11 & 1 \\
\hline
\end{tabular}

Table 4 is examined, eight teacher candidates (ÖE1, ÖE2, ÖE4, ÖK9, ÖK12, ÖK16, ÖK17, ÖK23) associated Land Art with three disciplines; 11 teacher candidates (ÖE3, ÖE7, ÖK5, ÖK10, ÖK11, ÖK13, ÖK15, ÖK18, ÖK19, ÖK20, ÖK21) associated Land Art with two disciplines; and four teacher candidates (ÖE6, ÖK8, ÖK14, ÖK22) associated Land Art with only one discipline. In total, nine disciplines were found to be associated with Land Art. The number of teacher candidates who simultaneously associated Land Art with Geography, and Art and aesthetics was nine (ÖE2, ÖE3, ÖE4, ÖK5, ÖK13, ÖK16, ÖK18, ÖK20, ÖK23). As a result of this association, the number of teacher candidates who simultaneously associated Land Art with Geography and History was also nine (ÖE1, ÖE2, ÖE4, ÖK9, ÖK10, ÖK12, ÖK16, ÖK17, ÖK21). Another finding that drew attention was the number of teacher candidates who associated Land Art with Art and aesthetics, History and Geography, - there were three - and the aforementioned are the three disciplines most associated in the study (ÖE2, ÖK4, ÖK16).

It is seen in Table 4 that most association is with the discipline of Geography, that is, that the technical fieldtrip is carried out within the scope of the Geography course, 
and that the products revealed are also made up of geographical elements. At the beginning of the field trip, the teacher candidate associated the theoretical knowledge given by the first and second author of the study with the products they developed during the application phase, which is considered the second part of the trip and the course coverage. This can be seen as the main reason why most association is with Geography. The fact that the Land Art event is related to art may have caused students to associate this event with the art and aesthetics course they took in the same semester. In addition, Land Art has also been associated with the discipline of History at high frequency. Geography and the environment were experienced as the scene and witness to historical events. Therefore the teacher candidates say the study evokes the discipline of history in the first place. History is closely related to Geography, and the interpretation that an application made from land elements can also offer examples of the discipline of History can be seen as the main reasons why Land Art can also be associated with History. Looking at the views of the teacher candidates, it was seen that the associations with disciplines are in line with the products revealed by the groups.

All of the teacher candidates associated Land Art with at least one but no more than three disciplines. However, the reasons how or why they believe Land Art relates to that discipline have not been answered by every teacher candidate. This is only expressed by some teacher candidates. Some of the teacher candidate's views on the subject include:

"Our practices can be associated with Geography, History and Art and esthetics (ÖE2).”

"It can be associated with History. Historical events can be depicted as far as the possibilities in nature. Figures of the historical event can be made with mud, leaves (ÖE6)."

"We can use this art in the subjects we will teach in Geography, History and Anthropology classes (ÖK9)."

"It can be associated with the discipline of Art and esthetics and Philosophy. Since interpretation is made in both (ÖK11)."

"It can be associated with Geography and History. It can be associated with all disciplines that actually exist (ÖK21)."

"Land Art has a relationship with Art and aesthetics. Because with my practice, both knowledge and art have emerged (ÖK22)."

\section{Teacher Candidates' Views About How the Use of Land Art as A Teaching Material in Extracurricular Activities Can Contribute to The Teaching of Geography and Related Subjects in Social Studies}

The opinions of teacher candidate on the contribution of the use of Land Art as a teaching material to the teaching of Geography and related subjects included in the Social Studies curriculum are given in Table 5. 
Table 5

Participants' Views About Land Art's Contribution to The Teaching of Geography and Related Subjects in Social Studies

\begin{tabular}{ccc}
\hline $\begin{array}{c}\text { Opinion on the state of } \\
\text { contribution of Land Art to } \\
\text { the teaching of subjects }\end{array}$ & Participants & f \\
\hline Making learning permanent & $\begin{array}{c}\text { ÖE1, ÖE2, ÖK5, ÖE6, ÖE7, } \\
\text { OKK8, ÖK9, ÖK10, ÖK11, ÖK13, } \\
\text { ÖK15, ÖK16, ÖK17, ÖK18, } \\
\text { ÖK19, ÖK20, ÖK23 }\end{array}$ & 17 \\
\hline $\begin{array}{c}\text { Embody information with } \\
\text { applications }\end{array}$ & $\begin{array}{c}\text { ÖE1, ÖE3, ÖK8, ÖK9, ÖK11, } \\
\text { ÖAK16 }\end{array}$ & 6 \\
\hline $\begin{array}{c}\text { Contributing to the teaching } \\
\text { of subjects through learning } \\
\text { by doing-living }\end{array}$ & ÖE7, ÖK17, ÖK21, ÖK22, \\
ÖK23 & 5 \\
\hline $\begin{array}{c}\text { Providing a fun learning } \\
\text { environment }\end{array}$ & ÖK8, ÖK14 & 2 \\
\hline $\begin{array}{c}\text { Ensuring that information is } \\
\text { busier and more persistent }\end{array}$ & ÖE4 & 1 \\
\hline Facilitating course teaching & ÖK19 & 1 \\
\hline Making the lesson popular & ÖK12 & 1 \\
\hline
\end{tabular}

The second question asked in the survey form is whether Land Art can be used in the teaching of Geography or if the availability of Land Art forms the initial phase of the application process, while Land Art's contribution to the teaching of subjects forms the final part of the process. At this point, because Land Art reflects an application and a process, the teacher candidates expressed the view that the contribution of Land Art was at the end of the process since it cannot be looked at in advance. In the study, the view that Land Art makes learning permanent was the opinion expressed by the vast majority of the working group. Opinions such as making theoretical knowledge permanent was related to Land Art being an application process, so information can be embodied, and each stage of application is a learning process by doing and living. Also, this constitutes views that are closely related to each other. It is effective that these expressions stated as opinions are closely related to each other, that the training is carried out in practice and that it ultimately contributes to the teacher candidates and the learning of the course in this way. Teacher candidates used statements that the Land Art event, which they personally experienced in collaboration, provided a fun learning environment, made the knowledge more active and permanent, made the course easier to teach and endeared students to the course. Some of the teacher candidate's views on the subject are as follows:

"It contributes to providing more permanent learning (ÖE2)."

"Due to the clear visual revival of Geography subjects in the head, it contributes to the busier and more practical information (ÖE4)."

"Because it is practical, it contributes to making information permanent in the minds of students (ÖK5)." 
Kayacilar, C., Karaca, A., (2020). Teacher Candidates' Views about Land Art in Geographical...

"Because a student does something through activity, that is, through his own effort, it becomes more permanent to learn, and it is also more difficult to forget (ÖK10)."

"The practice of Land Art contributes to ensuring that students love and learn the lesson (ÖK12)."

\section{Social Studies Teacher Candidates' Views About Using Land Art in Their Professional Lives}

In the open-ended questionnaire teacher candidates were asked if they wanted to use Land Art as an out-of-school activity in a Social Studies lesson in their professional life. All participants stated they intend to use this activity in their professional lives.

Table 6

Reasons for participants to choose Land Art as an outdoor school activity in their professional lives

\begin{tabular}{|c|c|c|}
\hline $\begin{array}{l}\text { Opinion on the reason why } \\
\text { Land Art is preferred in } \\
\text { professional life }\end{array}$ & Participants & $\mathbf{f}$ \\
\hline $\begin{array}{l}\text { I'd like to use it because it } \\
\text { provides permanent learning. }\end{array}$ & $\begin{array}{c}\text { ÖE1, ÖE2, ÖE3, ÖE4, ÖK5, } \\
\text { ÖK9, ÖK10, ÖK11, ÖK12, } \\
\text { ÖK13, ÖK14, ÖK16, ÖK18, } \\
\text { ÖK20, ÖK21, ÖK23 }\end{array}$ & 16 \\
\hline $\begin{array}{c}\text { I'd like to use it because it } \\
\text { provides learning by having } \\
\text { fun. }\end{array}$ & ÖE4, ÖK8, ÖK10, ÖK17, ÖK22 & 5 \\
\hline $\begin{array}{c}\text { I'd like to use it because it } \\
\text { makes the student active and } \\
\text { willing. }\end{array}$ & ÖE4, ÖK14, ÖK19 & 3 \\
\hline $\begin{array}{l}\text { I'd like to use it because it } \\
\text { integrates with nature. }\end{array}$ & ÖK23 & 1 \\
\hline $\begin{array}{l}\text { I would like to use it because } \\
\text { it is useful for the physical } \\
\text { development and health of } \\
\text { the student. }\end{array}$ & ÖE4 & 1 \\
\hline $\begin{array}{l}\text { I'd like to use it because it } \\
\text { develops spiritual feelings. }\end{array}$ & ÖE7 & 1 \\
\hline $\begin{array}{l}\text { I'd like to use it because a lot } \\
\text { of things are learned through } \\
\text { apps without realizing it. }\end{array}$ & ÖK10 & 1 \\
\hline $\begin{array}{l}\text { I'd like to use it because it } \\
\text { boosts your imagination. }\end{array}$ & ÖK15 & 1 \\
\hline $\begin{array}{l}\text { I'd like to use it because it } \\
\text { gives me environmental } \\
\text { awareness. }\end{array}$ & ÖE6 & 1 \\
\hline
\end{tabular}

Table 6 shows the opinions of prospective teachers about their preference for Land Art as an out-of-school activity in their professional lives. Teacher candidates indicated they would prefer Land Art in their professional lives, citing multiple and different reasons in accordance with their experience in the land. It is seen that teacher candidates will prefer Land Art activities in their professional lives with the idea that it provides permanence in learning as the main reason. Land Art 
mentioned in Table 6 provides a fun learning environment (ÖE4, ÖK8, ÖK10, ÖK17, ÖK22), provides integration with nature (ÖK23), is useful in the physical development and health of the student (ÖE4), increases imagination (ÖK15) and develops spiritual feelings (ÖE7), such as the idea that reasons are remarkable reasons for choosing in professional life.

\section{What Are the Characteristics of Land Art Products Created by Social Studies Teacher Candidates?}

In this section, the results of the Land Art activities carried out by the teacher candidates in the field are included. In the study, Land Art samples are presented by teacher candidates in the form of five separate groups. The samples were conveyed by a group spokesperson through the Land Art Product Evaluation Form.

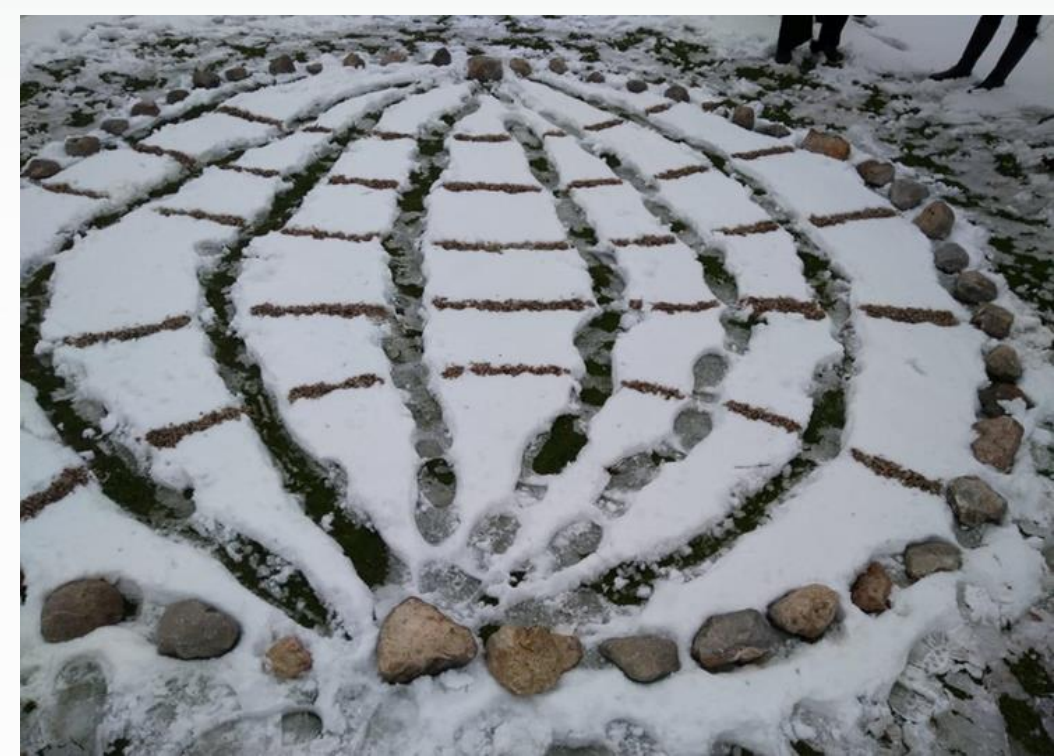

Figure 4. Land Art which group 1 performs which natural elements in the land

Table 7

Group 1 findings on Land Art Product Evaluation Form (LAPEF)

Art product name: Earth coordinate system on snowy ground

Materials used: Snow, stone, gravel, mud, footprints

Number of group elements: 6

Time taken by the product (minutes): 50

Product description of the Group 1 Spokesperson: "Without the use of artificial substances, which exist spontaneously in nature and ensure harmony with the natural environment that nature has offered us; Stone, snow, etc. we implemented our application with elements. In our world shape made with these materials, we reflected the equator, Meridian, polar points and rotating regions, that is, Geography as a whole with art, with our group Friends: "We found that this event clearly demonstrated the interdisciplinary relationship. This event showed our group of six how to use imagination, creativity and limited materials found in the field in difficult conditions. In our future professional life, we have concluded that we can use applications with love, as it shows how students can experience by doing-living and use limited opportunities in a fun way." 
Kayacılar, C., Karaca, A., (2020). Teacher Candidates' Views about Land Art in Geographical...

Possible educational attainments: "Our product can be effective in understanding the Earth coordinate system, determining mathematical position, expressing the shape and dimensions of the earth, and providing the ability to use imagination and creativity in the process of material development. Our product can make children learn with pleasure and embody the knowledge for children."

\section{Average representative score given by all groups: 4}

Observer notes: The researchers observed that Group 1 was quite compatible with each other in itself. They had no shortage of time in material development, and each group member acted responsibly. As a condition observed and negatively stated by the researchers, Group 1's inability to use their hands effectively due to contact with frozen soils, land and water to obtain mud under cold weather conditions is shown to produce crops on land.

The research concluded that with the Land Art product of Group 1, they effectively use the field and can relate Art and Geography. The product is thought to reflect the imagination and creativity of the group in a way that is considered positive and successful. In the study, it was found that the group found the Land Art activity useful in the development of imagination and creativity. In the field, it has been observed that the group reveals its product by having fun and collaborating. Group members have stated that they can also use Land Art with love in their professional lives, as it shows how students can experience by learning-by-doing and use limited opportunities in a fun way. This view shows that teacher candidates who first met the event found the Land Art event useful and useful in teaching subjects. In the study, it was observed that the teacher candidates liked the Land Art product of Group 1 and verbally expressed to the group members that it reflected the formal characteristics of the world. In the study, it was observed that a group of six people used the time to produce products comfortably and were the first group to complete their products collaboratively.

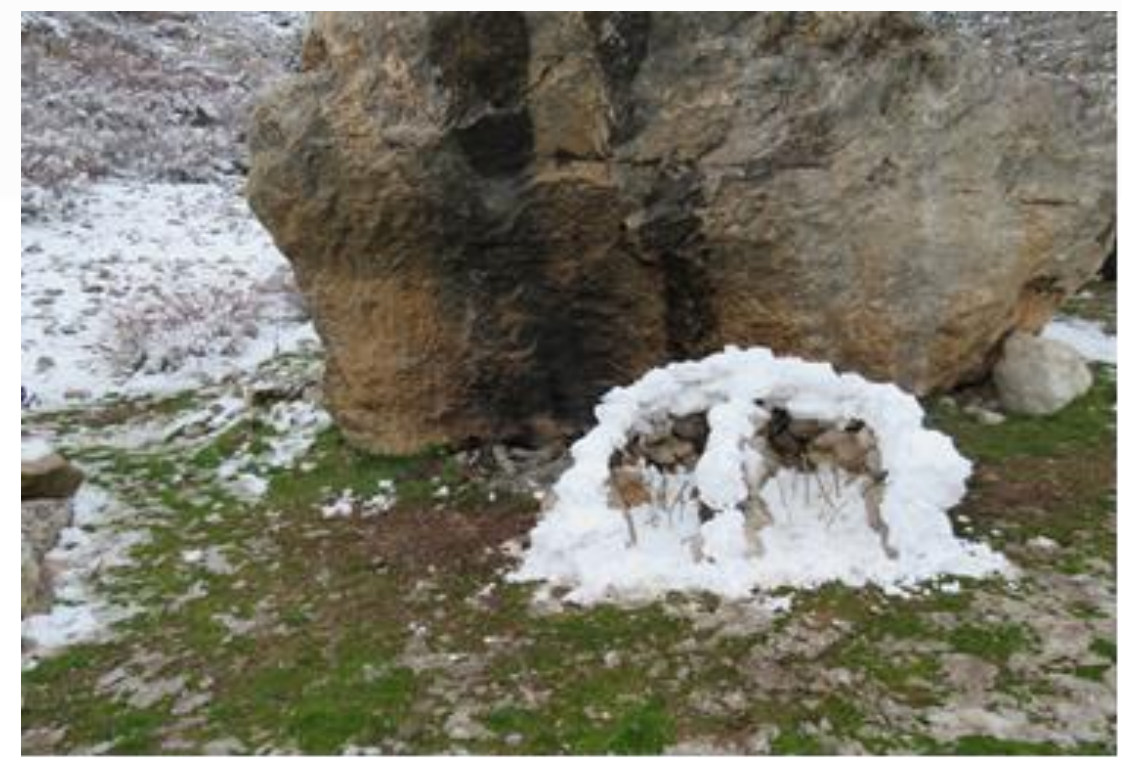

Figure 5. Land art, which Group 2 performs with natural elements in the land 
Table 8

Group 2 Findings on Land Art Product Evaluation Form

Art product name: Aladağlar topography as a miniature model for Karst and glacial topography

Materials used: snow, stone, gravel, mud, tree branch

Number of group elements: 4

Time taken by the product (minutes): 50

Product description of the Group 2 Spokesperson: "The valleys, trees, hills, snowfall and atmospheric events we saw inspired by nature have affected us deeply. The inspiration we received from our surroundings led us to do this event. As a group of four, we tried to show the reflection of Aladağlar with trees, rocks and snow. This event has been a great lesson to us about the sense of protecting the environment that has been going on since time immemorial and leaving this legacy intact for the future."

Possible educational attainments: "Our product can make it easier to understand and understand the topographic structure of the land. It can provide awareness of geomorphological formations, issues such as spatial perception and environmental sensitivity in the process of material development."

Average representative score given by all groups: 3

Observer notes: The researchers observed that Group 2 is highly compatible with each other in itself; they have a lack of time in material development, and think a lot about what elements and what can be done. Another observer note was the fact that there were differences of opinion in revealing the miniature state of topography.

In the study, it was observed that Group 2 was influenced by the topographic structure of the land in revealing the Land Art product and this was reflected on its products. Based on the group's opinion, it can be interpreted that the group is aware of protecting and maintaining the environment with the Land Art product, and that they draw attention to this situation with their products. The group assessed the effectiveness of Land Art as useful in the development of issues such as spatial perception and environmental sensitivity. It has been seen that land and land elements force students to think about what can be done with different, creative and existing elements in nature, and this causes students to lose some time in the process of developing materials. In the study, it was noted that some teacher candidates said that the product revealed by the group could not fully reflect the product title. In this, it may have been effective for the group to reflect the topography of the Aladağlar from their point of view with the elements they found in the land and to experience differences of opinion. In the study, it was observed that the group used the time given in the product development process to the end. 


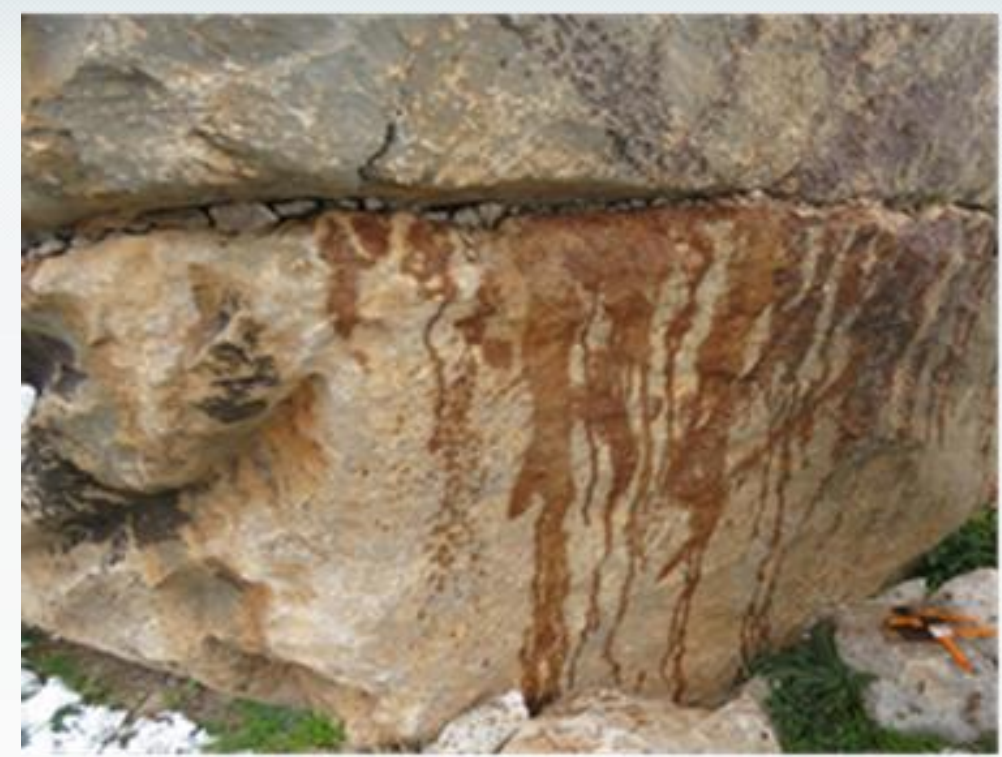

Figure 6. Land art, which Group 3 performs with natural elements in the land

Table 9

Group 3 Findings On Land Art Product Evaluation Form

Art product name: demonstration of infiltration action on cracks by providing an aesthetic image of crevices in rocks with gravel and clay mud

Materials used: rock surface, clay, water, gravel, brush

Number of group elements: 5

Time taken by the product (minutes): 50

Product description of the Group 3 Spokesperson: "As a group of five, we filled the crevices with stones of various sizes. In this way, we gave an aesthetic image to the natural structure without damaging it and combined art and geography. At the same time, we made natural paint from water, clay and soil to make the appearance of water seeping through the stones obvious, and we made the flow evident through spraying and leaking. Here, we have created a beautiful and eye-pleasing image without harming the environment by artistically making natural paint from nature. This allowed us to learn Land Art by seeing Geography and Art together in nature."

Possible educational attainments: "Our product can be used in the Association of art and geography. It can provide awareness of physical and chemical dissolution and soil structure. Environmental destruction can be noted with our product. Our product can be effective in developing skills such as environmental sensitivity and environmental protection awareness."

Average representative score given by all groups: 3

Observer notes: The researchers observed that Group 3 was quite compatible with each other in itself, had no shortage of time in developing materials, and members acted responsibly. In addition to the association of Art and Geography, the fact that each of the group members is original and free in brushstrokes has also been another observer note.

In the study, it was found that Group 3 relates art and geography to environmental destruction and natural structure conservation in product development. It has been observed that they act with aesthetic concern when revealing their products. The group evaluated its products as useful in the development of environmental sensitivity and environmental protection awareness. In the study, teacher candidates stated that the infiltration action on the rock surface was demonstrated and that the product was compatible with the title. 
It has been observed that the group does not have a shortage of time during the product development process and they fill the entire time comfortably.

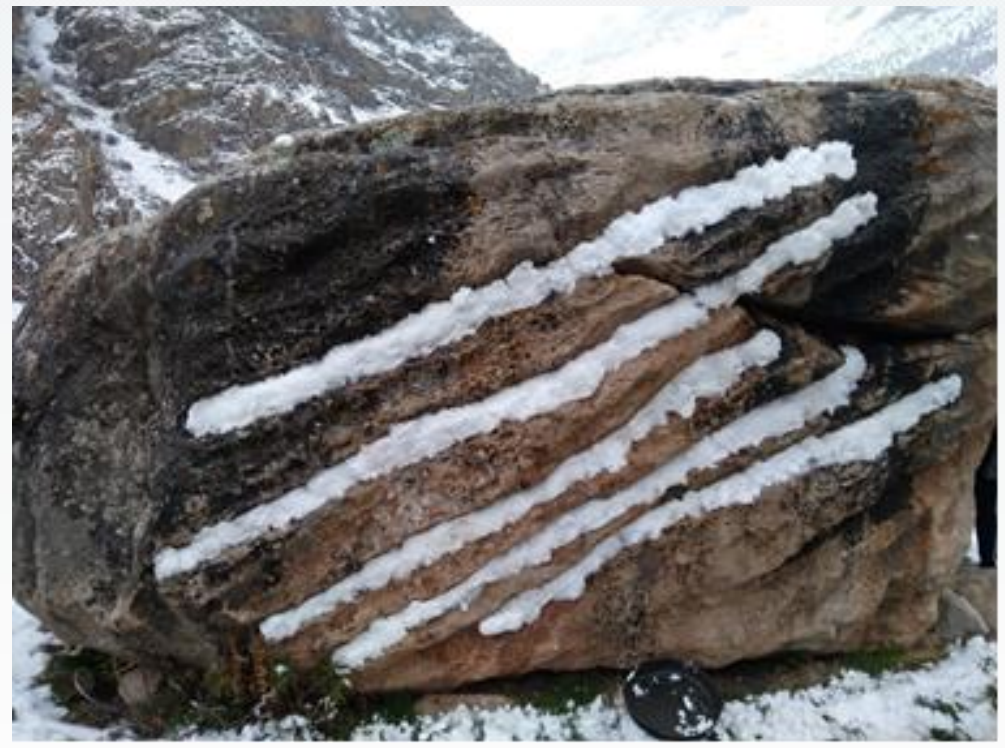

Figure 7. Land Art, which Group 4 performs with natural elements in the land

Table 10

Group 4 Land Art Product Evaluation Form

Art product name: drawing-decor work caused by filling porridge grooves with snow

Materials used: rock surface, snow

Number of group elements: 4

Time taken by the product (minutes): 50

Product description of the Group 4 Spokesperson: "At this event, we integrated the streams with nature by filling the eroded grooves with snow and created a vivid image. We learned the forms of wear from the beginning and practically understood how they were formed. This activity will be useful to us when we become teachers in the future, and we will also apply the activity to our students. Our group of four has combined practice with art with this event."

Possible educational attainments: "Our product can be effective in understanding issues such as stream topography, erosion and accumulation patterns and obtaining permanent information. Our product can be used to see the relationship between Art and Geography."

Average representative score given by all groups: 3

Observer notes: The researchers observed that Group 4 was quite compatible with each other in itself, had no shortage of time in developing materials, and members acted responsibly. In addition, due to their excessive contact with snow, the band members told each other that their hands were very cold, was another observer note.

The research showed that Group 4 can relate Art and Geography to its products. It was noted that the group found the effectiveness of Land Art to be useful in teaching subjects. Members of the group stated that they would also prefer a Land Art activity in their professional lives. In the study, it was found that conditions such as weather conditions being challenging and teacher candidates not being able to prepare for the field affected group performance. In the study, teacher candidates 
stated that the product of the group and the product title were compatible. The group has completed the time given for product development on a full-time basis.

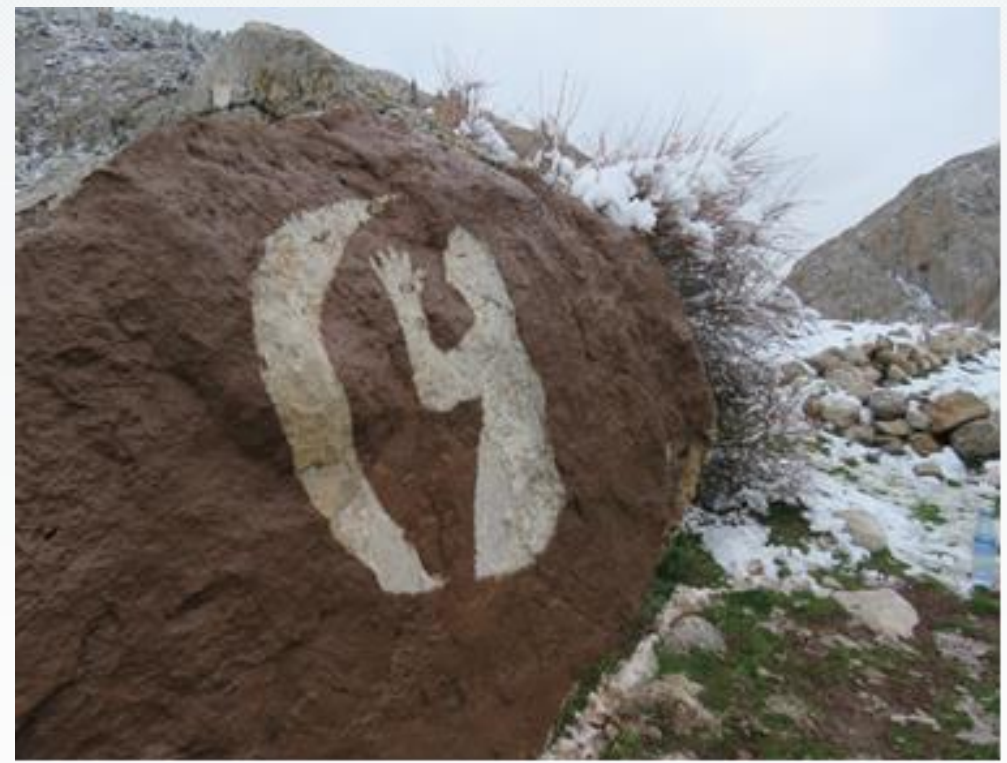

Figure 8. Land Art, which Group 5 performs with natural elements in the land

Table 11

Group 5 Land Art product evaluation form

Art product name: an example of cave art made of clay mud on the rock surface

Materials used: rock surface, stone, mud

Number of group elements: 4

Time taken by the product (minutes): 50

Product description of the Group 5 Spokesperson: "This is the first time we have tried this art. It was a very different, engaging and fun experience for us. As a group of four, we drew our figure with limestone on the falling rock and painted the rest with a mixture of red soil and water. For us, it was a great trip that we will not forget, we were very happy to study in Niğde as Geography. In the future, we very much want to take our students to the land. It will be a very different and lasting experience for students to learn by living of all the Geography lessons, it was the lesson we learned the most by living"

Possible educational attainments: "Our product can be an exemplary model in understanding issues such as rock formation, rock and soil structure and in revealing the relationship between Geography and Art."

\section{Average representative score given by all groups: 4}

Observer notes: The researchers observed that group $\mathrm{V}$ was quite compatible with each other in itself, had no shortage of time in developing materials, and that members acted responsibly. Another situation was observed that the group had quite a lot of fun in putting out products.

The research found that Group 5 correlates art and geography with its product. It has been observed that group members have fun in revealing their products and express this as an opinion. It was found remarkable that the members of the group described the technical field trip as the lesson in which they learned the most of all 
Geography lessons. With this view, it can be inferred that the event has achieved its purpose and is useful and useful in educational settings. Members of the group stated that they would also prefer Land Art activity in their professional lives as an opinion. The terrain favorable for the Land Art event of the province they live in and the fun passing of the The technical field trip was a situation that the group described as happiness. In the study, teacher candidates stated that the product of the group fully reflected the product title and that they liked the product very much. The band used the entire time given and finished last in the event due to the fact that they painted the entire rock surface.

\section{Results and Discussion}

Interesting and positive results were obtained from the open-ended survey and product evaluation form about the Land Art event held during the technical fieldtrip in the mountain-geography course. There were $20(86.96 \%)$ participants out of the 23-teacher candidate Working Group who did not have any idea about Land Art and its examples until this research occurred. For the first time, these participants had ideas and knowledge. In the study, it was found that only three teacher candidates could identify Land Art or who had previously only heard its name. These three teacher candidates were female and comprised $13.04 \%$ of the study group. All of the male teacher candidates, who comprised $26.09 \%$ of the study group, did not have an idea about art at the level of hearing, identifying and providing detailed information before the event. As such, this supports the results from the current research that female students are more interested in Art and aesthetics than male students. In their study, Taşkesen (2014) and Alıcı (2019) concluded that female students are more interested in Art than male students.

The products revealed by the groups in the study were also qualified as teaching material by the teacher candidates. Characterizing products as materials can also be associated with concrete, meaningful and permanent learning, which are other views mentioned in the research. An increased imagination, development of creativity, and support of the course with these products when there is a shortage of materials were also reasons given for seeing Land Art as suitable teaching material. Evaluating the resulting products as materials also demonstrates the importance of using such materials in teaching to make theoretical knowledge concrete and provide lasting learning. This result also supports the conclusion that the use of materials achieved by Avşar (2010), Çapar (2012), Kıy Can (2009) and Yazıcı (2017) is effective in teaching. Land Art products are an alternative teaching material that can support learning environments.

In the current research, Land Art products have been associated with Geography, Art and aesthetics, History, Science, Anthropology, Social Studies, Sociology, Archaeology, and Philosophy. Making associations with 9 separate disciplines in total also shows the richness of the Land Art products. The discipline most associated with Land Art activities was Geography (69.57\%). The other disciplines with which the activity was most associated were Art and aesthetics (52.17\%) and History (52.17\%). It can be said that the most association of Land Art is with 
Geography, and that the technical fieldtrip is carried out within the scope of the Geography course, and that the products revealed contain geographical elements. Reasons for teacher candidates saying Art and aesthetics as the second most recognized discipline for the association of Land Art may be related to the teacher candidates taking an Art and aesthetics course in the same semester as this research. Reasons for the association between Land Art and Art and aesthetics courses include the presence of art in the name of Land Art, its appeal to the environment and the eye, the aesthetic dimension of the activities, and the presence of Art and aesthetics courses. Efthymia, Vasiliki and Konstadinosve (2012) concluded that Land Art facilitates the understanding of subject content through interdisciplinary learning in their work with pre-school teacher candidates. In his work, Rigaud (2012) tackles Land Art and the myth of the discovery of the Americas; he associated Land Art with Geography, Earth Science, Art, History, Philosophy, Culture, and History. Given that achieving permanence in learning may be possible with the interdisciplinary association of Land Art and the transfer of interdisciplinary knowledge, it can be said that the relevant studies and this current research have reached similar results.

The products revealed by the groups in the study are also an indicator of how much theoretical knowledge is possessed by teacher candidates and at what level such knowledge exists. As a result of this indicator, students or groups reveal their materials in two or three dimensions and thus embody what they know. Given the findings of the open-ended survey and Land Art Product Evaluation Form, teacher candidates saw the emerging products as a result of the event in which they described the materials of Land Art as being of benefit to ensuring that student learning is relevant and the student is actively participating in the course. This result also aligns with research by Gökçe (2009) in his study about increased levels of interest in the course and reasons for active participation.

In the current research, it was found that Art can be used to raise awareness about Geography and sub-branches of Science. From the views from teacher candidates about the use of Land Art in the teaching of subjects, it was put forward that Land Art would help to educate students as naturalists. This result was found to be quite remarkable. The role of educating students as naturalists also gives Land Art a serious and scientific activity or a systematic project process. According to Thomas (2000), students create their own knowledge by actively learning, interacting with the environment as suggested by the constructivist approach, working independently, or by collaborating in teams. Teachers, on the other hand, manage and direct this process, and eventually a real product appears. The realization of the Land Art product within a project is seen as an effective reason for applying Land Art to the teaching of the subjects, as it is also a solution material to the pre-determined problem situation. Aslanides, Kalfa, Athanasiadou, and Karapatsias-Gianelos (2016), suggest the advantages of project-based learning works in this way; it is a process which helps students to better understand the experiential and empirical information collected during the course rather than being a passive message recipient host. By teachers facilitating the learning of 
students who are working on a specific project, students are able to acquire information and skills from different courses and participate in a project to combine all the information and learning which helps to overcome the limits of motivation related to classical teaching methods. A study by Wood (2003) suggests that problem-based learning as a constructivist approach provides some of the benefits of students active learning. By encouraging an approach to maintain and develop the lifelong learning skills becomes fun for students and teachers, and in the process, all students are required to participate in the learning process which makes students to interact with concepts as part of everyday activities associated with instructional materials to be provided.

From this point of view, installing a problem situation in Land Art or thinking of Land Art as a project will bring positive returns to the educational process and Land Art itself. In addition, the use of Land Art as an activity in project and problem-based learning in the relevant disciplines will also expand the area of use, as it can be addressed in every discipline. In this study, the fact that a person identifies or feels himself as a naturalist at the end of the process at the Land Art event, and that people will therefore prefer it in their lessons and professional life, shows the seriousness of such an approach to the event and the benefit of the product eventually reached. Based on this result, it is possible to say that Land Art is a referable application in project and problem-based learning.

In the current study, it was concluded that all teacher candidates would prefer Land Art effectiveness in their professional lives by linking it to various reasons. The idea that a Land Art event will create a connection between the student and the teacher and develop the student's spiritual feelings has been a very noticeable expression in the research. Zachariou and Valanides (2006) expressed the view that a target of sustainable development for outdoor school education is to help them examine the impact on teachers of critical thinking, creativity, interactive and experiential learning design, and implementation of innovative pedagogical activities. It can be said that the findings such as the development of spiritual feelings, the development of imagination and the increase of creativity reached in this study touch the same points as the aforementioned study. Fly (2010) listed many reasons for Land Art to promote an increase in interaction with nature, knowledge of nature, and an increase in academic performance. Such reasons include developing a persistence in learning; being fun for students in their work; providing a special place and experience for students to create special memories; increasing students' interaction with friends, teachers and other community and group members; gaining better social interaction skills; and contributing to the development of physical and mental health through activity. The results achieved by Fly (2010) are a summary and a strong basis for the results revealed in this study. In addition to the goals of the course, the student also gains a sense of interaction and belonging with the physical and social environment in which he or she lives. 
It was a result of the study that Land Art activity was as much a product of collaborative work as it was individual. In the study, it was found that groups were affected by the weather conditions and the lack of preparation for the land when producing products, and it was concluded that before such events, they should be dressed in accordance with the current land and climatic conditions. During the development of the Land Art product, it was observed that some students had difficulty finding the idea of an art project and made joint decisions by conducting discussions within the group in this direction. In the study, it was observed that the groups experience as an active learning process was noted because they interact with both materials in nature and each other when producing an art project. In the study, it was also observed that teacher candidates as a group and as individuals, use their creative thinking skills to think about what they can do with the materials they have, and they experience seeing details by looking carefully at their surroundings while searching for land elements around them. "Hence, interaction and communication skills between teacher candidates and groups were intense. Cooperative learning also improves individuals' skills that help them develop their social skills and work with higher performance in a better work environment" (Artvinli, 2010). As a result of this situation, the products produced by the groups were realized through cooperation, reaching a common decision and taking responsibility.

In the current study, the participant groups critically evaluated each other's work and scored accordingly. The Land Art product of Group 1 (Earth coordinate system) and Group 5 (A sample painting of cave art made from clay mud on the rock surface) were the most appreciated products by the teacher candidates at the event. Teacher candidates verbally stated these products literally reflect what they want to reflect, and that the product and product title are quite compatible. Such products were awarded 4 points (very good) by groups. The products of Group 2 (topography of Aladaglar), Group 3 (demonstration of infiltration action on cracks) and Group 4 (pattern-decor work caused by filling porridge grooves with snow) were awarded 3 points (good) by the groups.

Looking at the relationship between the group member and duration in the study, it is believed that both conditions are independent of each other. It can be said that the main factor determining the performance of groups is limited by time in product identification, so this affects the natural elements they find in the land for the products and products that the group wants to create. A group with a large number of members may want to put out fewer demanding products, or a group with a small number of members may want to put out products that are quite laborious and above the group's performance. In the same way, it can be said that the status of cooperation and responsibility of the groups, regardless of the number of members, also affects the performance of the group. In the study, four-member Group 5 (made of clay on the rock surface, an example of cave art) is the last group to finish the work, so its products are time-consuming, and five-member Group 3 (showing the act of infiltration on cracks by providing an aesthetic image with gravel and clay 
mud) also shows a less laborious product, so there is no shortage of time. From this point of view, products designed by groups, product construction stages and group communication and interaction are considered as a situation independent of the relationship with duration.

In the current study, the results from the survey and Land Art Product Evaluation Form support each other. Therefore, the idea arises that Land Art as an outdoor school activity can contribute to the development of environmental awareness and provide students with the opportunity to develop a positive attitude towards the science of nature and Geography. From the survey findings of the current study, it is seen that teacher candidates do not directly associate Land Art activity with environmental education. However, in the Land Art Product Evaluation Form, some groups emphasize environmental awareness. Teacher candidates did not feel the problem of environmental pollution intensely as they carried out a technical field trip in a high-altitude mountain ecosystem and in a more remote area to settlements. Due to this situation, environmental education may not be given priority in the survey and evaluation form. Zachariou and Valanides (2006) stated that in their study about the existence of a direct relationship occurring with the environment, it is the outdoor school education program that helps teacher candidates to improve their knowledge about environmental issues and accurately conceptualize the systemic and holistic character of environmental problems. In the related study, it was found that outdoor school educational activities help teacher candidates understand that environmental problems are not only related to the natural dimension of the environment but also related to its social, political and economic dimension. "In order for sustainable development conscious to be improved, students have to hold the environmental attitude" (Artvinli and Demir, 2018, p. 33). In this context, Land Art can be an effective and highly meaningful way of sustainable development at the end by making important contributions to the development of environmental awareness.

The fact that the environment in which art takes place reflects almost all the physical and human elements of Geography also raises questions about space, the use of space and the integration of spatial information into different areas. Places containing physical and human elements where educational activities are carried out also reveal the use and importance of space in geographical education due to the use of the environment. This situation is the fifth goal under the heading of Special Objectives in the Social Studies Course Curriculum is "to explain the interaction between human and environment by recognizing the general geographical features of the world with the environment in which it lives and to develop the skills of perceiving space" (MoNE, 2018, p. 8). The importance of the environment in spatial perception skills arising from the living environment as the sixth goal under the title of Special Objectives in the Social Studies Course Curriculum is "to recognize the limitations of the natural environment and resources and try to protect natural resources in the context of environmental sensitivity and have a sustainable understanding of the environment" (MoNE, 2018, p. 8). 
Land Art, where the limitation of subject and space cannot be made, is seen as an applicable activity in educational settings for the development of environmental sensitivity, environmental awareness and spatial perception skills. Efthymia, Vasiliki and Konstadinos (2012) stated in their study that Land Art is a basic teaching tool in the training of teacher candidates to teach environmental education. Therefore, Land Art should be part of daily teaching methods used in all teacher education programs. Land Art is a type of art performed in the environment, so it belongs to the environment in which it is located. At the same time, this type of art is an element of environmental art. The most important thing in environmental art is that actions have artistic and ecological meaning in the same place at the same time. Therefore, environmental art belongs to both art education and environmental education (Stathopoulou, 1997). In the work of Zachariou and Valanides (2006), teacher candidates realized that taking care of the environment, together with developing sensitivity and environmental awareness is not only teaching and learning about the environment, but also a process with active participation. From this window, Land Art, can be a part of environmental art and occupies an important position in art and environmental education. The findings of this study also partially support this condition.

Based on the findings, Land Art creates a fun learning environment and makes it possible to popularize geography lessons. This finding also coincides with Yazicl (2017) who, in his study about the integration of gravel art into Geography teaching, finds that Art makes the lesson fun.

\section{Suggestions}

Based on the findings and results of the current research, it is possible to make the following suggestions:

- Land Art, which contributes positively to students' aesthetic understanding, imagination, and awareness about the environment and discipline of Geography, can often be applied to the teaching of subjects in Social Studies and Geography courses.

- A Land Art event can be used as an enriching event for fieldtrips organized in the teaching of Geography.

- Geography can be used as a tool for multi-disciplinary project work, where learning environments are associated with other disciplines such as Art, Aesthetics, and History.

- In Social Studies courses supported by materials from Land Art products, it is observed that Land Art can be used to establish inter-course associations.

- Land Art activities can provide permanence in teaching and make teaching fun; such activities can also be applied to popularize Geography lessons.

- The contribution of Land Art activities to learning can contribute to the field by designing with a mixed method of research to offers qualitative and quantitative data. 
- Investigation about how Land Art activities can contribute to learning, especially by examining the process dimension, can occur.

- Educational research can be conducted on how Land Art can be used in disciplines other than Geography.

\section{References}

Aktın, K. (2020). Reflection on out-of-school education activities from the textbooks to the Social Studies Curriculum. Review of International Geographical Education (RIGEO), 10(3), 373-399. doi: 10.33403rigeo.705615

Alıcl, Ş. (2019). Analyzing the relation between students' interest in art and their style for handling stress in faculty of education. (Unpublished master thesis). Erzincan Binali Yıldırım University Institute of Social Sciences, Erzincan. Retrieved from: https://tez.yok.gov.tr

Andy Goldsworthy Digital Catalogue. (1986). Woven branch circular arch Langholm, Dumfriesshire [DVD]. Retrieved from: https://www.goldsworthy.cc.gla.ac.uk /image/?id=ag_03744

Artvinli, E. (2010). Configuring of geography lessons: Design of a lesson based on action research. Marmara Geographical Journal, 21, 184-218. Retrieved from https://dergipark.org.tr/tr/download/article-file/3204

Artvinli, E., \& Demir, Z. M. (2018). A study of developing an environmental attitude scale for primary school students. Journal of Education in Science, Environment and Health (JESEH), 4(1), 32-45. DOI:10.21891/jeseh.387478

Aslanides C. D., Kalfa, V., Athanasiadou, S., Gianelos, Z. \& Karapatsias, V. (2016, September). Advantages, disadvantages and the viability of project-based learning integration in engineering studies curriculum: the Greek case. Paper presented at the meeting of 44th SEFI Conference, Finland.

Avşar, S. (2010). Geography subject in secondary school social studies of the use of student achievement effects of instructional materials (Karabük province example). (Unpublished master thesis). Selçuk University Institute of Educational Sciences, Konya. Retrieved from: https://tez.yok.gov.tr

Aydın, A. (2014). Earth art in Turkey. (Unpublished master thesis). Gazi University Graduate School of Fine Arts, Ankara. Retrieved from: https://tez.yok.gov.tr

Beyoğlu, A. (2015). Land art and contribution to education of contemporary art: New style in nature and space integration. TOJET: The Turkish Online Journal of Educational Technology, Special Issue 2, 347-355. ISSN: 2146-7242

Büyüköztürk, Ş., Kılıç Çakmak, E., Akgün, Ö. E., Karadeniz, Ş., \& Demirel, F. (2012). Scientific research methods (Rev. Ed. 12th ed.). Ankara: Pegem Akademi.

Creswell, J. W. (2007). Qualitative inquiry \& research design: Choosing among five approaches (2th ed.). USA: SAGE Publications.

Çapar, M. (2015). A study on andy goldsworthy's using nature as an artistic material (the case of Çukurova University). Journal of Çukurova Research, 1(1), 165-177.

Çapar, T. (2012). The impact of effective use of materials by geography teachers on students' levels of attitude, academic success and ability to remember: Izmir case study. 
Kayacılar, C., Karaca, A., (2020). Teacher Candidates' Views about Land Art in Geographical...

(Unpublished doctoral thesis). Dokuz Eylül University Institute of Educational Sciences, İzmir. Retrieved from: https://tez.yok.gov.tr

Çınar, H. S., \& Yirmibeşoğlu, F. (2019). Art formed on land; land-art. In O. Boydaş \& S. Ödemiş (Eds.), Research articles in the field of fine arts. (pp. 69-82). Ankara: Gece Akademi.

Çırak Karadağ, S. (2019). Psychosocial achievements of social studies teacher candidates in outdoor geography courses. Review of International Geographical Education Online (RIGEO), 9(3), 663-677. DOI: 10.33403/rigeo.580824

Demiralp, N. (2007). Materials in geography education and the geography curriculum 2005. Kastamonu Education Journal, 15(1), 373-384.

Doğanay, H., \& Sever, R. (2011). General and physical geography (10th Edition). Ankara: Pegem Akademi.

Duran, E. M. (2015). The concept of nature in the 21st. century painting. (Unpublished master thesis). Çanakkale Onsekiz Mart University Institute of Social Sciences, Çanakkale. Retrieved from: https://tez.yok.gov.tr

Efthymia, G., Vasiliki, G., \& Konstadinos, C. (2012). Implications of the land art training for kindergarten teacher trainees on their interdisciplinary teaching practices. US-China Education Review, 12, 1021-1025. ISSN 1548-6613

Fly, J. M. (2010). A Place-Based Model for K-12 Education in Tennessee. Retrieved from: https://moam.info/the-place-based-education-model-the-university-of-tennessee_598af31c1723ddcd698896f5.html\#: :text=Place\%2DBased\%20Education\%20(PB E),curriculum\%20(Sobel\%2C\%202005).

Gökçe, N. (2009). Project on preparing instructional material for general and physical geography. international Journal of Geography and Geography Education (Marmara Geographical Journal), 20, 20-41.

Hancock, D. R. \& Algozzine, B. (2006). Doing case study research: a practical guide for beginning researchers. Teachers College Press, 1234 Amsterdam Avenue, New York.

Kedik, A. S. (1999). Land art in the context of the changing view of the relationship between art and audience and the concept of time. Retrieved from: https://earsiv.anadolu.edu.tr/xmlui/bitstream/handle/11421/1232/141077.pdf?s equence $=1$ \&isAllowed $=\mathrm{y}$

Kedik, A. S. (2010). Richard long: allusions of a walk. Art and Design Journal, 1(5), 107-120.

Kiy Can, S. (2009). The effect on the success of the students by using material in social lesson 4 th and 5th classes in primary school (Kars province example). (Unpublished master thesis). Kafkas University Institute of Social Sciences, Kars. Retrieved from: https://tez.yok.gov.tr

Lanzani, L. F. (2013). Land art as a landscape opportunity? Land art as a new form of landscape research. Retrieved from: https://www.l2arch.com/ATM2103_ LANZANI\%20Lorenzo\%20Francesco_Land\%20art\%20as\%20a\%20landscape\%20o pportunity.pdf.

MEB [Ministry of National Education] (2018). Social Studies Curriculum (Primary School and Secondary School 4th, 5th, 6th and 7th Grades). Retrieved from: http://mufredat.meb.gov.tr/ProgramDetay.aspx?PID=354. 
Mergin, A. (2018). The language and space relationship between duration, process and representation process in the context of the land art and the space: the existing life of artist. (Unpublished master thesis). Işık University Institute of Social Sciences, İstanbul. Retrieved from: https://tez.yok.gov.tr

Nichols, D. R. (1982). Outdoor educators: the need to become credible. The Journal of Environmental Education, 14(1), 1-3.

Özayten, N. (1992). In west object art/conceptual art/ post-conceptual art and related trends between 1965-1992 year in Turkey. (Unpublished doctoral thesis). İstanbul University Institute of Educational Sciences, İstanbul. Retrieved from: https://tez.yok.gov.tr

Renkçi Taştan, T. (2016). Artists and works within the art, nature and technology. Ídil, 5(19), 169-180.

Rigaud, A. (2012). Disorienting geographies: land art and the American myth of discovery. Miranda [Online]-Open Edition Journals, 6, 1-15. Retrieved from: https://journals.openedition.org/miranda/2955.

Rogers, A. (n. d.) Land art: gift. Retrieved from: https://www.andrewrogers.org/landart/turkey/the-gift/

Solberg, I. (2016). Land art in preschools. An art practice. International Journal of Education \& the Arts, 17(21). Retrieved from: http://www.ijea.org/v17n21/.

Stathopoulou, P. (1997). Teaching about environment through art. Retrieved from: http://www.naturearteducation.org/Articles/Pani\%20Stathopoulou\%20article.pdf ?origin=publication_detail

Tandoğan, O., \& Erdi Es, B. (2018). Land art around the world and in Turkey. Iddil, 7(51), 1359-1368.

Taşkesen, S. (2014). A study on the relation between personality type of students of high school and their interest in art. (Unpublished master thesis). Gazi University Institute of Educational Sciences, Ankara. Retrieved from: https://tez.yok.gov.tr

Topaç, V. (2015, 27 March). Some of my works. [Blog post]. Retrieved from: http://vtopac.blogspot.com/

Thomas, J. W. (2000). A review of research on project-based learning. San Rafael, CA: The Autodesk Foundation. Retrieved from: https://pdfs.semanticscholar.org/8d83/ f329aac63db3c67599f76323e37ace4a53bd.pdf?_ga=2.81674768.686612637.15964 88910-1779662419.1596488910

Tilki, H. (2018). The fall of the wall and land art. Tykhe Art and Design Journal, 3(5), 308324.

Uzunokur, O. (2011). A general overview to land art on the axis of andy goldsworthy. (Unpublished master thesis). Işık University Institute of Social Sciences, İstanbul. Retrieved from: https://tez.yok.gov.tr

Üçışık, S., Ünlü, M., \& Özey, R. (2002). Importance of photographs in geography educatıon and instruction. International Journal of Geography and Geography Education (Marmara Geographical Journal), 5, 1-8. Retrieved from: https://dergipark.org.tr/tr/pub/marucog/issue/452/567512

Wood, D. F. (2003). Problem based learning. British Medical Journal, 326, 328-330. 
Kayacilar, C., Karaca, A., (2020). Teacher Candidates' Views about Land Art in Geographical...

Yağmur, Ö. (2016). Art of the nature shaping: Land Art. Idil, 5(27), 1977-1988.

Yazıcl, Ö. (2017). Integration of pebble art in teaching geography. The Journal of Social Science, 4(18), 406-427

Yıldırım, A., \& Şimşek, H. (2018). Qualitative research methods in the social sciences (11th ed.). Ankara: Seçkin Yayıncılık.

Zachariou, A., \& Valanides, N. (2006). Education for sustainable development: the impact of an out-door program on student teachers. Science Education International, 17(3), 187203.

\section{Biographical Statements}

Cengiz KAYACILAR is an assistant professor in the Department of Turkish and Social Sciences Education at the Niğde Ömer Halisdemir University. His areas of interest include the teaching of geography in social studies education, disaster education and physical geography.

Ayten KARACA is a $\mathrm{PhD}$ student at Niğde Ömer Halisdemir University Institute of Educational Sciences. Her areas of interest include social studies education, geography education and Lesson Study Model in development of teaching profession. 